Prof. dr Slavko Vukša ${ }^{30}$

Prof. dr Dragan Anđelić ${ }^{31}$

Ilija Kolarski M.A. ${ }^{32}$

stručni rad

UDK: $338.124 .4 ; 336.1 / .5$

\title{
ULOGA EKONOMSKE POLITIKE U EKONOMSKIM KRIZAMA
}

\section{REZIME}

Ekonomska kretanja ukazuju na neuravnoteženost i nejednoličnost u odvijanju osnovnih ekonomskih procesa, odnosno na činjenicu da je kapitalizam obeležen procvatima i propastima, recesijama i ekspanzijama koje se ponavljaju. Počev od 1825. godine i prve ekonomske krize, prisutni su usponi i padovi u odvijanju svetske ekonomije. U visoko razvijenoj tržišnoj privredi neka zemlja može da u određenom periodu ostvaruje ekonomsku ekspanziju i prosperitet, praćen ubrzanim rastom brutodomaćeg proizvoda, realnog-dohotka, investicija, zaposlenosti. Ovakav trend praćen je i određenim merama fiskalne i meonetarne politike, čije greške u vođenju često uslovljavaju da iz blagostanja država zapadne evrope ulaze u krizu koju karakteriše rast nezaposlenosti, pad bruto-domaćeg proizvoda, pad profita i dr. Negativni saldo u većini makroekonomskih pokazatelja posle određenog perioda dostiže dno, nakon čega počinje oporavak privrede koji može da traje kraće ili duže vreme.

Ključne reči: ekonomska politika, ekonomska kriza, recesija, neoliberalizam.

\section{UVOD}

Snažan ekonomski rast u dvadesetom veku, većeg broja zemalja, uslovio je povećanje životnog standarda njihovih stanovnika i na taj način uticao na stvaranje svesti o državi blagostanja i životu bez problema. Taj rast je neminovno vodio ka globalizaciji, čime je svet sve više postao povezan, a nove tehnologije su uslovile stvaranje konkurentnijeg globalnog tržišta. Ova povezanost uslovila je i mogućnost da promene u ekonomskom sistemu jedne zemlje se reflektuju i na ostale ekonomije sveta, u zavisnosti od snage date ekonomije, a što može da ima i negativne posledice u vidu kriza hiperprodukcije.

Problemi makroekonomske nestabilnosti, a posebno poslovnih ciklusa pratile su razvoj ljudskog roda od početka devetnaestog veka pa do danas. Sve tržišne ekonomije pokazuju znake ekonomske ekspanzije i kontrakcije koje nazivamo poslovnim ciklusima. ${ }^{33}$ Periodi blagostanja i ekonomskog rasta uslovljavali su pogrešan stav da se u određenom trenutku teorije poslovnih ciklusa zanemare (u periodu nakon Velike depresije 1929-1933 do sedamdesetih godina dvadesetog veka se čak smatralo da se ekonomska kriza više nikada neće javiti). Međutim, ostvariti makroekonomsku stablnost cena, dohotka i zaposlenosti su ciljevi čijem se ostvarenju mora težiti svaka tržišna ekonomija, a poslovni ciklusi i njihove silazne putanje moraju se pratiti i prihvatiti kao nerazdvojivi deo savremene ekonomije.

\section{NEOLIBERALIZAM I EKONOMSKE KRIZE}

Neoliberalna ekonomska politika svoje instrumente delovanja na ekonomiju vidi u privatizaciji, deregulaciji, smanjivanju poreza. Neoliberalizam kao ekonomska politika tržište smatra glavnim regulatorom ekonomskih aktivnosti. Međutim, potpuna regulacija tržišta nije moguća iz razloga što postoje drugi faktori koji utiču na tu regulaciju, što znači da se i neoliberalizam primenuje samo u određenim granicama. Kako je konstatovano da je neoliberalizam nepravilan i diskriminatorski prema različitim klasama, on $s$ tim u vezi pravi jedna pravila za bogate tako što im omogućuje određene subvencije koje predstavljaju konkretan primer intervencije, dok siromašnim zemljama iste takve subvencije strogo zabranjuje.

"Neki ekonomisti smatraju da se globalizacija pretvorila u fenomen da se bogati osećaju gospodarima u celom svetu, a da se siromašni osećaju slugama i u svojoj vlastitoj zemlji". ${ }^{34}$

\footnotetext{
30 Univerzitet za poslovne studije Banja Luka

31 Univerzitet za poslovne studije Banja Luka

32 Računovodstevni centar, Ministarstvo odbrane

33 Samjuelson P., Nordhaus V., Ekonomija, 18. izdanje, MATE Zagreb, 2009, str. 406

34 M.Babić, Makroekonomija, Mate, Zagreb, 2007, str. 640.
} 
Može se zaključiti da za siromašne zemlje u tim situacijama vrede načela i ideologije kapitalizma, dok za bogate zemlje vrede načela i ideologije socijalizma. Konkretan primer imamo i u današnjem vremenu kod razvijenih i bogatih zemalja koje su upravo bili zagovornici neoliberalizma, gde se u kriznim situacijama daju određene subvencije i ostale vladine intervencije, dok u mirnim i stabilnim situacijama u kojima postoji ekonomski rast i razvoj o takvim vrstama vladinih intervencija nema ni govora. Neoliberalizam svoju ekonomsku politiku realizira putem medunarodnih finansijskih institucija kao što je svetska banka, međunarodni monetarni fond, itd.

Kao što je i sam John Williarnson iz Instituta za rnedunarodnu ekonomiju iz Washingtona, i idejni tvorac Washingtonskog konsenzusa sam rekao da u njegovim preporukama koje je izneo u Washingtonskom konsenzusu nije biio preporuka koje su se ticale monetarizma, slobode kretanja kapitala, minimalnih poreza, ekonomike ponude, kao i koncepta tzv."minimalne države", a koji se smatraju osnovnim preduslovima za ekonomski rast i razvoj privrede.

$U$ današnjem vremenu se izraz neoliberalizma veže za ideje Washingtoskog konsenzusa i globalizacije. ${ }^{35}$

Budući da se neoliberalna ekonomska politika odnosno neoliberalizam bazira na preporukama Washingtonskog konsenzusa koji je krajem 90 -tih godina XX veka predstavljao rešenje za oporavak zemalja Latinske Amerike od tadašnjih ekonomskih kriza, to znači da, te preporuke Washingtonskog konsenzusa predstavljaju instrumente neoliberalne ekonomske politike za izlazak iz globalnih ekonomskih kriza. To potvrđuje i činjenica da je pojavom globalnih ekonomskih kriza krajem XX veka, te preporuke iz Wašingtonskog konsenzusa za određene reforme dobili globalni karakter i korišćeni su za oporavak svetskog tržišta od tih novonastalih kriza. Kod zemalja pogođenih krizama dolazi do odliva kapitala te upravo zbog toga preporuke koje nudi Washingtonski konsenzus imaju za cilj povrat tog izgubljenog kapitala usled ekonomskih kriza.

Implementacija tih preporuka se sprovodi uglavnom kroz makroekonomsku disciplinu sa posebnim akcentom na fiskalnu oblast, tržišnu privredu i liberalan stav prema svetskoj ekonomiji, a posebno prema direktnim stranim ulaganjima. Kao što je poznato, Wašingtonski konsenzus se sastoji od ukupno 10 tih preporuka:36

- Prva preporuka se odnosi prvenstveno na fiskalnu oblast, budući da zemlje pogođene ekonomskim krizama ostvaruju vrlo visok fiskalni deficit koji dovodi do inflacije. Ta inflacija uglavnom pogađa siromašnu populaciju zbog činjenice do bogata populacija svoje bogatstvo može ili preneti u inostranstvo ili ga pak konvertovati u neku drugu čvrstu valutu.

- Da bi se potpomogao u rastu i razvoju taj siromašni deo populacije koji i najviše nastrada u ekonomskim krizama, i na taj način privreda zemlje koja se nalazi u krizi što pre oporavila i usmerila u pozitivnom rastu i razvoju, druga preporuka koju predlaže Washingtonski konsenzus se odnosi na preusmeravanje javnih rashoda u obrazovanje, zdravstvo i infrastrukturu.

- Treća se preporuka odnosi na poresu reformu kojom bi se stvorio poresi sistem koji bi imao umerenu graničnu poresku stopu ali i širu poresku osnovicu. Naime, zemlje pogođene ekonomskim krizama realizuju vrlo mala ulaganja i investiranja, a ovom poreskom reformom bi se obezbedila povoljnost za ulaganja.

- Četvrta preporuka je da se stvori liberalna kamatna stopa, ali istovremeno osigura i mudra supervizija finasijskih institucija. Kao i kod prethodne preporuke ovom preporukom bi se stvorile povoljnije kamatne stope za uzimanje kredita koji bi se isto tako uložili u određene investicije.

- Peta preporuka se odnosi na stvoranje takve kursne politike koja će obezbediti konkurentnost izvoza. Ovde je u pitanju izvoz koji usled ekonomskih kriza ima veoma nisku stopu, a povećanjem izvoza bi se obezbedio unos finansijskih sredstava u zemlju.

- Šesta preporuka je da se omoguće uslovi za liberalnu trgovinu. Naime, zemlje pogođene ekonomkim krizama beleže vrlo nisku stopu trgovine. Leberalizacijom trgovine ta bi se stopa povećala.

- Sedma preporuka je, obezbediti uslove za liberalizaciju direktni stranih ulaganja. Ovom preporukom bi se obezbedila finansijska sredstva za zemlje pogođene ekonomkim krizama, koja bi došla direktnim stranim ulaganjima, a koja bi se usmerila i koristila za oporavak privrede.

- Osma preporuka je privatizacija državnih preduzeća, ali pod uslovom da se tome pristupi sa oprezom jer pored pozitivnih konsekvenci koje ostavruje privatizacija kao što je razvoj konkurentnog tržišta, bolja kvaliteta usluga, itd., lošim pristupom privatizaciji, ona ima i svoje negativne konsekvence kao što je korupcija, zbog koje se državna imovina prodaje po vrlo niskim cenama u odnosu na njihovu stvarnu cenu. Kao i kod sedme preporuke ovom

\footnotetext{
35 Ibidem, str. 637.

${ }^{36}$ M.Kesner-Škreb, Washingtonski koncenzus, Finansijska teroija i praksa, 28(2), 2004, str. 251-251.
} 
preporukom bi se između ostalog obezbedila finansijska sredstva koja bi se usmerila za oporavak tržišta.

- Deveta preporuka se odnosi na deregulaciju, ali treba istaći da ta deregulacija se ne odnosi na izmenu nekih pravila nego uopšteno samo na stvaranje jednostavnijeg načina za ulazak na tržište ali isto tako i izlazak sa tog tržišta.

- I deseta poslednja preporuka se odnosi na vlasnička prava u cilju jasnog tržišnog poslovanja.

- Kako se može videti iz priloženog, krucijalne preporuke se odnose na uređenje monetarne i fiskalne politike, liberaliziran pristup investicijama i spoljnoj trgovini, privatizacija, deregulacija.

\subsection{Uticaj instrumenata neoliberalizma na globalne ekonomske krize}

Uticaj neoliberalizma na tržišta je ograničen i uslovljen drugim faktorima regulacije. Budući da neoliberalizam svojim delovanjem daje određene pogodnosti bogatim dok siromošnoj klasi stvara određene restrikcije i nepogodnosti, ncoliberalizam se iz tog razloga smatra nepravednim i diskriminatorskim.

Oprečna su gledišta kada je u pitanje efikasnost delovanje neoliberalne ekonomske politike. U slučaju ekonomske krize koja je zadesila Latinsku Ameriku 1990. godine, neoliberalna ekonomska politika sprovođena putem principa Washingtonskog konsenzusa je dovela do toga da je s jedne strane zabeležen privredni rast, inflacija je postala niža, budžeti su stabilizovani, spoljna zaduženost je smanjena; dok istovremeno s druge strane druge zemlje beleže povećanje stope nezaposlenosti, što je dovelo do povećanja stope siromaštva. Upravo liberalizacija tržišta koja je proistekla iz principa Washingtonskog konsenzusa je ta ista tržišta destabilizovana i oslabila, jer je omogućila kratkoročnom privatnom kapitalu ulazak na tržište ali isto tako još brži izlazak sa tog istog tržišta. Potvrdu činjenice da je neoliberalizam neefikasan ekonomski sistem dale su i finansijske krize koje su se nastavile širiti po svetu, a posebno po Azijskom kontinentu. Brojni ekonomisti su se pozabavili ispitivanjem efikasnosti tržišnih reformi kroz deregulaciju i liberalizaciju. U tom ispitivanju te efikasnosti mnogi ekonomisti su imali jedinstven stav o efikasnom delovanju samo prve tri preporuke iz Washingtonskog konsenzusa, a koje se odnose na fiskalnu oblast (fiskalna disciplina, preusmeravanje javnih rashoda, poreska reforma).

Oni smatraju i glavni akcenat stavljaju na razvoj institucija i ravnomeran raspored dohotka kao krucijalan faktor razvoja zemalja, a koji su upravo kroz Washingtonski konsenzus maksimalno zapostavljeni i kojima se pridavao minimalan značaj. Oni su smatrali da, što su institucije razvijenije da je država razvijenija, a kada je u pitanju ravnomeran raspored dohotka u korist siromašnog stanovništva, taj se problem može rešiti da se poveća ukupan iznos prihoda pa da svakoga sledi po veći udeo, ili s druge strane da se progresivno oporezuju bogati i iz tih prihoda da se finansira socijalno osiguranje siromašnih. Kada se analizira efikasnost neoliberalne ekonomske politike realizovane kroz međunarodne finansijske institucije, mnogi ekonomisti se slažu da i tu ima dosta propusta i nelogičnosti. Jedan od takvih primera je i sistem tzv."isti model za sve", koji podrazumeva ista pravila za sve zemlje koje traže pomoć od tih međunarodnih finansijskih institucija. Naime, eksperti ovih institucija nepoznavajući situaciju i stanje određenih zemalja uglavnom su prisiljeni da pružaju ista pravila za svaku zemlju. Budući da države koje traže pomoć od tih međunarodnih finansijskih institucija se nalaze u bezizlaznim situacijama, one bezuslovno prihvataju tu uslovljenu finansijsku pomoć bez prethodno pripremljene svoje unutrašnje strategije razvoja.

Budući da neoliberalizam kao ekonomska politika zbog drugih faktora zbog kojih je uslovljen u svom delovanju, nemože potpuno da deluje na tržišta u pravcu zaustavljanja i smirivanja negativnog dejstva globalnih ekonomskih kriza, te usmeravanja tržišta u pravcu stvaranja pozitivne konjukture i privrednog rasta, neoliberalizam kao ekonomska politika je stavljen na ispit prolaznosti ili pak nekog novog restruktuiranja u nekom novom obliku neke druge ekonomske politke.

\section{DELOVANJE KENZIJANIZMA NA GLOBALNE EKONOMSKE KRIZE}

Kejnsijanska ekonomska politika svoje instrumente delovanja na ekonomiju vidi u državi i njenom uticaju vođenjem politikc agregatne potražnje. ${ }^{37}$

Kejnsijanizam kao ekonomska politika u borbi protiv globalnih ekonomskih kriza i prvenstveno se koristi fiskalnom politikom kojom prvenstveno utiče na agregatnu potražnju ali i na agregatnu ponudu. Bez obzira na suprotna gledišta koje imaju kejnsijanci i monetarsiti kada je u pitanju suprostavljanje globalnim ekonomskim krizama, u borbi protiv globalne ekonomske krize nastale 2007. godine, i jedni i drugi su pristupili instrumentima fiskalne politike kako bi ublažili negativne posledice globalne ekonomske krize. Kao što su mnogi svetski ekonomski stručnjaci konstatovali, nevidljivoj ruci Adama Smitha potrebna

\footnotetext{
37 Agregatna potražnja predstavlja zbir svih individualnih tražnji na jednom tržištu. Agregatna tražnja utiče na cenu proizvoda i usluga na način da rast agregatne tražnje dovodi do rasta cena, dok pad agregatne tražnje dovodi do pada cena.
} 
je vidljiva ruka Johna Maynarda Keynsa kako bi se zaustavile krize na svetskim tržištima. Karakteristika globalnih ekonomskih kriza ogleda se kroz smanjenje izvoza i svih vidova potrošnje, od lične, budžetske, pa do investicijske potrošnje. Tako je i ova globalna ekonomska kriza u prvom redu delovala na potrošnju čime se odrazio negativan multiplikujući efekat na proizvodnju.

Kejnsijanizam kao ekonomska politika ima stajalište da za zaustavljanje negativnog dejstva krize je potrebna ravnoteža između fiskalne i monetarne politke. Oni monetarnu politiku nestavljaju u neutralan položaj kada je u pitanju suprostavljenje globalnim ekonomskim krizama. Kada je u pitanju izvlačenje privrede iz krize i njeno oživljavanje, kejnsijanci u prvi plan stavljaju tzv. Kejnsov efekt oživljavanja. Kod država koje ostvaruju nacionalni dohodak manji od moguće ostvarljivog nacionalnog dohotka, država treba primeniti fiskalnu politiku kojom bi se inicirala i povećala agregatna potražnja, zaposlenost i proizvodnja. Naime, javnom potrošnjom se direktno, dok se oporezivanjem indirektno utiče na stabilizaciju nacionalnog dohotka države, a posebno one države koja je pod uticajem različitih turbulencija na svom tržištu. Svaka promena u primeni fiskalne politike koja podrazumeva javnu potrošnju i oporezivanje, utiče na promenu agregatne potražnje. Važno je naglasiti da u zdravim uslovima na tržištu, tržište najbolje alocira resurse i distribuira nacionalni dohodak. Međutim, u situaciji kada se tržište nalazi pod uticajem krize država svojim instrumentima mora nadoknaditi nastali propust.

S tim u vezi, javna potrošnja i oporezivanje igraju tu tzv. alokacijsku ulogu koja podrazumeva alokaciju sredstava unutar različitih dobara. Pored alokacijske uloge vrlo važan značaj se pridaje i distribucijskoj ulozi koju igra javna potrošnja i oporezivanje, a koja se ogleda u mogućnosti ravnomerne raspodele nacionalnog dohotka na različite korisnike, od krajnjeg pojedinca pa sve do regija unutar države. To znači da javna potrošnja i oporezivanje odnosno fiskalna politika predstavljaju sistem koji omogućuje ravnomernu raspodelu nacionalnog dohotka, jer u suprotnom slučaju, kod neravnomerne raspodele nacionalnog dohotka bogati postaju još bogatiji, dok siromašni postaju još siromašniji. Takav nesklad i nesrazmer u raspodeli nacionalnog dohotka jedan je od osnovnih uzroka nastanka globalnih ekonomskih kriza.

S tim u vezi, interesantan podatak zasnovan na uzorku 94 zemlje koje imaju konstantno vođenu bazu statističkih podataka od 1960. godine do 2002. godine kaže da početkom 60-tih godina prosečan bruto domaći proizvod po glavi stanovnika u 20 najrazvijenijih zemalja je iznosio oko $11.417,00$ \$ dok je u 20 najnerazvijenijih zemalja iznosio svega 212,00 \$. Nakon 40-tak godina kada je i globalizacija doživela svoj najveći vrhunac, bruto domaći proizvod po glavi stanovnika u 20 najrazvijenijih zemalja je iznosio $32.339,00$ \$, dok je u 20 najnerazvijenijih zemalja iznosio $267,00 \$ .38$

Kao što je konstatovano najefikasniji instrument kada je u pitanju alokacija resursa i distribucija nacionalnog dohotka je upravo fiskalna politika. Međutim, u situaciji kada se tržište neke zemlje nađe u nemilosti globalnih ekonomskih kriza stabilizaciona uloga koju tada poduzima fiskalna politika je neprikosnovena. Mnogi ekonomisti dele zajedničko gledište, a što je i ova globalna ekonomska kriza potvrdila da fiskalna politika ima krucijalnu ulogu u zaustavljanju krize te stvaranju uslova za sigurnu ponudu i potražnju. Pored diskrecijske fiskalne politike koja dakle igra krucijalnu ulogu u zaustavljanju nastalih kriza na tržištu, veoma veliki se značaj pridaje i tzv. automatskim stabilizatorima koji predstavlja oblik fiskalne politike kojim se sužava prostor za fluktuacije outputa bez prisustva mera poduzetih od strane države. Mnogi eminentni stručnjaci se slažu da je za sprečavanje širenja globalnih ekonomskih kriza neophodna primena instrumenata fiskalne politike. Tako je kod ove poslednje globalne ekonomske krize mera koju je preduzela vlada SAD-a bila ubrizgavanje finansijske injekcije na tržište SAD-a u iznosu od oko 700 milijardi \$. Jedan od takvih eminentnih svetskih stručnjaka je i Američki ekonomist Nouriel Roubini koji je kazao da su ta sredstva koja čine samo 5\% BDP SAD-a su nedovoljna za saniranje svih troškova nastalih pojavom krize.

Osim toga, Nouriel Roubini je i ukazao na propust u poduzetim merama od strane vlade SAD-a, kao što je nepostojanje plana fiskalnih stimulansa u formi tradicionalne kejnsijanske potrošnje kojima bi se inicirala agregatna polražnja, kao i nepostojanje adekvatne institucije kojom bi se nastali dug restruktuirao. On je dao primer institucije Home Owners' Loan Corporation (HOLC) koja je osnovana u vreme Velike depresije 1929. godine kako bi se tadašnji dug restruktuirao. ${ }^{39}$

Budući da proizvodnja i zaposlenost brže opadaju nego što se menjaju cene na tržištu, usled čega dolazi do naglih promena na tržištu, a koje se ne može relativno brzo prilagoditi tim nastalim promenama, samim tim se nameće kao neophodna intervencija države. Uloga države a tom slučaju se ogleda u ublažavanju ili pak usporavanju pada potražnje koja utječe na proizvodnju.

U pogledu intervencije države Kejns preporučuje monetarnu politiku (kamata, novac, formiranje kapitala, kredit), poresku politiku, politiku državnih rashoda (posebno transfernog,

\footnotetext{
38 ...zasnovano na uzorku 94 zemlje i teritorije od 1960. godine do 2002.godine a može se dobiti od World Bank, World Development Indicators, 2003 (online version), vidi - Lj. Jurčić: Finansijska kriza i fiskalna politika, Ekonomski pregled 5-6, 2010, str 321.

${ }^{39}$ Nouriel Roubini,"Is Purchasing $\$ 700$ bilion of Toxic Assets the Best Way to Recapilalizethe Financial System?" RGE-Finance \& Markets Monitor, Roubini Global Economics, Septembar 28, 2008, vidi - Ž.S.Petrac,: Karakter tekuće finansijske krize SAD i moguće globalne posledice, Biblid br. 4, 2008, str. 433.
} 
eproizvodnog'karaktera), kompletnu budžetsku anticikličnu politiku razrađenu na principima budžetskog deficita i javnog duga..$^{40}$

\subsection{Uticaj instrumenata kejnsijanizma na globalne ekonomske krize}

Instrument kejnsijanizma kojim se on suprostavlja globalnoj ekonomskoj krizi je u prvom redu fiskalna politika. Delotvornost uticaja fiskalne politike je već potvrđena i ona se ogleda kroz efikasno delovanje prvenstveno na agregatnu potražnju i ponudu.

$\mathrm{Na}$ agregatnu potražnju kao bitan faktor na tržištu ukoliko se ono nalazi pod uticajem eksternih dejstava, fiskalna politika može uticati na način da direktno deluje na budžetsku potrošnju, a indirektno na sistem oporezivaanja. Tim delovanjem fiskalna politika direktno utiče na stabilizaciju destabiliziranog nacionalnog dohotka. Adekvatna alokacija resursa i ravnomerna raspodela nacionalnog dohotka na jednom tržištu predstavljaju bitan faktor u prevenciji i suzbijanju ekspanzije globalne ekonomske krize. Upravo u tom segmentu se ogleda još jedna vrednost i važnost upotrebe fiskalne politike kao instrumenta kejnsijanske ekonomske politike. Fiskalni multiplikator je jedan od instrumenta fiskalne politike koji također ima veliki značaj u zaustavljanju globalne ekonomske krize. Kao što je poznato, uticaj globalne ekonomske krize se prvenstveno oseti na smanjenju svih vidova potrošnje, od lične potrošnje, budžetske potrosnje pa sve do investicijske potrošnje. Opšte poznato je da, pad potrošnje deluje negativno na proizvodnju. Fiskalni multiplikator predstavlja odnos u promeni bruto domaćeg proizvoda $(\Delta \mathrm{Y})$ kao rezultat promene fiskalnog deficita (AT) ili promene javne potrošnje $(\Delta G)$, a imajući u vidu domaći dohodak koji bi se ostvario da su navedene promene ostale nepromenjene.

Prema M. Babiću, veća granična sklonost oporezivanju i uvozu, smanjuje vrednost multiplikatora. $S$ tim u vezi vrednost multiplikatora će biti veća onda ukoliko se minimalan deo sredstava iz fiskalnog stimulansa usmeri na štednju ili uvoz. U suprotnom slučaju, povećana granična sklonost potrošnji, povećava samu vrednost multiplikatora. $S$ tim u vezi, potrošači se mogu opredeliti na povećanu Štednju kojom bi se mogli plaćati porezi u slučaju da oni pretpostave da će se sa povećanjem javne potrošnje povećati ti isti porezi. ${ }^{41}$

Ovde se ponovo potvrđuje važnost uskladenosti monetarne i fiskalne politike tj.njihovog sinhroniziranog delovanja, usled čega nedolazi do povećanja kamatne stope zato što je povećana javna potrošnja. Međutim, treba naglasiti i to, da i pored toga što sinhronizovana monetarna politika sa fiskalnom politikom dovodi do stabilizacije tržišta i povećanja same vrednosti multiplikatora, ona ukoliko se utvrde drukčiji ciljevi može negativno uticati na vrednost muitiplikatora. Jedan od instrumenata fiskalne poiitike kojim se ona suprotstavlja globalnoj ekonomskoj krizi jeste automatski stabilizator kojim se umanjuje nestabilnost outputa bez primene diskrecionih mera od strane države. Vrlo značajan instrument fiskalne politike jeste fiskalni stimulans čiji je zadatak da povećaju potrošnju krajnjih potrošača tj.domaćinstava, a u cilju rasta potražnje za robama široke potrošnje. Pored toga, fiskalni stimulansi se primenjuju i u poslovnom sektoru na način da se smanje troškovi kapitala odnosno pruži pomoć za sanaciju.

J.M.Keyns je shvatio vezu temeljne proturečnosti kapitalizma u smislu društvenog rada i privatnog prisvajanja sa temeljnim protivrečnostima dveju središnje institucije naše civilizacije, tržište i demokratije. Problem stihijskog delovanja tržišta u smislu da bogati postaju još bogatiji, siromašni još siromašniji rešio je uvođenjem indikativnog planiranja i koncepcijom i strategijom razvoja na koju se oslanja aktivna ekonomska politika. ${ }^{42}$

\section{DELOVANJE MONETARIZMA NA GLOBALNE EKONOMSKE KRIZE}

Monetaristi su mišljenja da se uzrok nastanka velike depresije nalazi u loše vođenoj monetarnoj politici od strane federalnih rezervi zbog čega je ponuda novca u tom periodu pala za ukupno $1 / 3$. Oni smatraju da sistem federalnih rezervi tada nije spustio ponudu novca za $1 / 3$ da ne bi došlo do velike depresije.

S tim u vezi velika depresija iz 1929. godine je imala veliki uticaj na samu monetamu politiku, a između ostalog i česte pojave inflacija koje su ograničavale tadašnju monetarnu politiku. Ta promena u monetarnoj politici se odnosila prvenstveno na njene nove ciljeve, a to su proizvodnja i zaposlenost. Pojavom globalne ekonomske krize 2008. godine važnost pune zaposlenosti i nadzora nad inflacijom kao dva primarna cilja monetarne politike ponovo su potvrđena.

P.Bernholz odnos novca i inflacije u ekonomsko političkom smislu svrstava u tri primarna zahteva. Prvi zahtev je ustanoviti metalni-zlatni ili srebrni standard koji ima puno manju tendenciju prema

\footnotetext{
${ }^{40}$ S.Komazec, Ž.Ristić, Makroekonomija, Etno Stil, Beograd, 2009, str. 318.

${ }^{41}$ M.Babić, Makroekonomija, Mate, Zagreb,2005, ili P.Jurković, Javne finansije, 2002, vidi Lj. Jurčić: Finansijska kriza i fiskalna politika, Ekonomski pregled 5-6, 2010, str 323.

42 Lj. Juričić, D. Vojnić: Latentna kriza kapitalizma "Društvo blagostanja” ili "Ekonomski neoliberalizam”, Zbornik, radova 19. Tradicionalnog savetovanja HDE, Opatija, 2011, str. 57.
} 
inflaciji. Drugi zahtev je papirni standard vezati za nezavisnu centralnu banku u političkom smislu, i treći zahtev da se papirni standard bazira na fiksnom deviznom kursu ili valutnom odboru. ${ }^{43}$ P.Bernholz smatra da ukoliko je ispunjen bilo koji od ova tri zahteva da će tendencija prema inflaciji biti drastično manja.

Kao i to je poznato, dolazak globalne ekonomske krize 2008. godine uslovio je pad agregatne potražnje, pa je u vezi s tim mere koje su poduzimane u cilju zaustavljanja globalne ekonomske krize odnosile se na mere u oblasti monetarne politke kako bi se podstakao rast agregatne potražnje i očuvala makroekonomska stabilnost. Jedan od načina pomoću kojega je monetarna politika povećavala rast agregatne potražnje jeste i snižavanje kamatnih stopa preko centralnih banaka. Međutim, budući da giobalna ekonomska kriza u prvom redu pogađa i bankarski sektor monetarna politika je bila okupirana spašavanjem mnogih banaka od bankrotstva. Poznata je i činjenica da su se mnoge države stavile na raspolaganje kao garanti štednih uloga tih banaka imajući u vidu činjenicu o propast mnogih banaka u vreme velike ekonomske depresije. Monetarizam kao ekonornska politika prioritet u borbi protiv globalnih ekonomskih kriza daje monetarnoj politici i friedmanovoj tzv.kvantitativnoj leoriji novca.

Prema M. Babiću. četiri verzije kvantitativne teorije novca su transakcijska teorija I. Fishera, verzija dohotka, Cambridge Cash-balances pristup, Friedmanova (restatement). ${ }^{44}$

Monetaristi novac smatraju kao osnovno sredstvo na tržištu pomoću kojeg se stbilizuje tržište. Monetarnom politikom se vrši kontrola ponude novca od strane centralne banke. Ta kontrola ponude novca se sastoji od dva pravca, i to: restriktivni - u kojem se ograničava i umanjuje ponuda novca, i ekspanzivni - u kojem se povećava ponuda novca na tržištu.

Budući da mnogi kvantitativnu teoriju novca smatraju teorijom nivoa cena, odnosno jednom od teorija inflacije, njen najveći zagovornik M. Friedman je dao objašnjenje da: Kvantitativna teorija novca je pre svega teorija potražnje za novcem. ${ }^{45}$

Pojavom inflacije dolazi do rasta kamata, dok pojava recesije ima suprotan učinak i ona smanjuje kamate. Monetarna politika kao oblik ekonomske politike svojim delovanjem može biti orijentisana u tri pravca i to, ekspanzivni pravac - masa novca raste brže od BDP, neutralni pravac - masa novca i BDP imaju proporcionalan rast, restriktivni pravac - masa novca raste sporije od BDP. Delovanje ekspanzivne monetarne politike ima za cilj da poveća masu novca na tržištu koje će dovesti do smanjenja kamatnih stopa koje će na kraju povećati investieije a time i BDP, proizvodnju i zaposlenost. Delovanje restriktivne monetarne politike ima potpuno suprotan učinak, ono će smanjiti masu novca na tržištu, povećati kamatne stope, smanjiti investicije, a što će rezultirati smanjenjem BDP, proizvodnje i zaposlenosti. Ciljevi monetarne politike su likvidnost, stabiinost, ravnoteža,itd.

\subsection{Uticaj instrumenata monetarizma na globalne ekonomske krize}

Utemeljitelj i osnivač monetarizma M. Friedman smatra da se velika depresija iz 1929. godine mogla pravovremeno zaustaviti da je FED , budući da je velika depresija krenula iz SAD-a, u pravo vreme povećao realnu masu novca kako bi privreda u takvim uslovima mogla nesmetano da funkcioniše.

Kada je u pitanju izvlačenje privrede iz krize i njeno oživljavanje, monetaristi u prvi plan stavljaju tzv. Pigouov efekt oživljavanja. ${ }^{46}$

Pigou nije pridavao značaj zamki likvidnosti za razliku od Kejnsa koji je pridavao značaj tome. Pigou je smatrao da kada raste realna vrednost postojeće imovine da ljudi tada podižu svoju tekuću potrošnju na račun štednje šte predstavlja tzv. Piguov efekt. ${ }^{47}$

Kod Piguovog efekta pad cena kao posledica depresije povećava bogatstvo i kupovnu moć što utiče na agregatnu potražnju, a na kraju i na rast društvenog proizvoda. Piguov efekat fokus stavlja na stvaranje uslova za automatski izlazak iz krize.

Razliku između dugoročnih i kratkoročnih posledica deflacije J. Tobin je konstatovao tako što je utvrdio da se Piguov efekat odnosi samo na dugoročne posledice. ${ }^{48}$

\footnotetext{
43 P. Berhnolz, Monetary regimes and inflation, Edward Elgar, 2003, vidi - M. Jakšić,: Svetska ekonomska kriza: Izazov za makroekonomsku teoriju, str. 8.

${ }^{44}$ M.Babić, Makroekonomija, Mate, Zagreb, 2007, str. 307.

45 M.Friedman:The quantity theory of money: A restatement, citiran prema R.W. Clower: Monetary theory, Penguin, 1969., str.95., vidi - M.Babić, Makroekonomija, Mate, Zagreb, 2007, str. 307.

46 Piguov efekat oživljavanja je pojam koji se odnosi na poticanje proizvodnje i zaposlenosti povećanjem potrošnje uzrokovane povećanjem bogatstva, osobito za vreme deflacije.

47 D.Ž.Marković, B.B.Ilić, S.Komazec, Ž.L.Ristić, D.D.Radovanović, Globalna ekonomija i geofinansije, Etno Stil, Beograd, 2011, str. 283.

48 J.Tobin, Keynesian models of recession and depression, American Economic Review, Papers and Procesings, 1975, vidi Ibidem, str. 283
} 


\section{KOMPARATIVNI PRIKAZ DELOVANJA NEOLIBERALIZMA I KEJNZIJANIZMA}

Početkom 90-tih godina XX veka, a na osnovu ideologije SAD-a koja se odnosila na liberalnu demokratiju i neoliberalnu ekonomije što se bazirala na minimainoj državnoj intervenciji na tržištu koje bi se u stvari samo regulisalo, mnogi su tada naivno prihvatili pobedu neoliberalne ekonomije. Od početka 30-tih godina pa sve do 70-tih godina XX veka, odnosno dolaska na vlast Ronalda Reagana, na tržišnoj sceni je bila zastupljena regulacija putem državne intervencije. Međutim, dolaskom na vlast Ronaida Reagana regulacija tržišta putem državne intervencije je počela da slabi na intenzitetu. Tada su počeli da primenjuju neki novi oblici instrumenata za regulaciju. Sa primenom tih novih regulatora tržišta, njihova stabilnost počinje slabiti $i$ dolazi do poremećaja na tržištu u smislu bankrotstava i rasta cena. Ti poremećaji su nakon toliko godina predstavljali blaže rane simptome globalne ekonomske krize.

Tada dolazi do pojave jednog novog proizvoda u bankarskom sektoru koji se naziva "credit default swap" čiji je osnovni smisao da banka osigura taj isti kredit u slučaju neizvršenja obaveze vraćanja kredita. ${ }^{49}$

$\mathrm{U}$ tom slučaju banka je zarađivala samo onu razliku između procenta kamate na dati kredit i procenta kojeg je davala za osiguranje tog istog kredita. U takvim uslovima kada su kreditni uslovi bili jako primamljivi i kada je rizik tog istog kredita preuzimala sama banka, došlo je do rapidne ekspanzije uzimanja tih kredita. Osiguranja tih kredita su enormno rasla, a iznosi su se merili u desetinama triliona. Međutim, upravo tu se je nalazila kardinalna zamka. Nije se imalo u vidu da propast bilo koje finansijske institucije u tom lancu, nastaje lančana reakcija koja se prenosi na ostale karike tog lanca, tj.na ostale finansijske institucije.

Tako je u gore navedenom slučaju prva se na udaru našla osiguravajuća kuća AIG koja nije mogla izmiriti svoje obaveze usled čega je nacionalizovana, a posledicu toga je osetila banka Lehman Brothers koja je bankrotirala. Počelo je dejstvo "finansijskog oružija masovnog uništenja" (W.Baffet). ${ }^{50}$ To je bio početak same lančane reakcije kao uvod u novonastalu globalnu ekonomsku krizu.

Još jedan konkretan slučaj neefikasnosti neoliberalizma može se uvideti u Azijskim državama 1997. godine, kada je masa finansijskih špekulanata ušla na njihova tržišta sa ogromnim kapitalom. Kada su realizovali svoje cieve zbog kojih su ušli u ta tržišta i kada su naišli na prve otpore na tržištu, na brzinu su izneli svoj kapital i ostavili devastirana tržišta. I u tom slučaju su države morale intervenisati kako bi rehabilitovale ta tržišta. Kako se može zaključiti iz odgovora vlada razvijenih zemalja, oni pod svaku cenu su spremni finansijski intervenisati u cilju oporavka bankarskog sektora i likvidnosti, bez obzira o iznosima koji su potrebni kako bi se navedeni sektori oporavili. Time je definitivno zadat poslednji udarac i pečat stavljen na neefikasnost neoliberalizma kao ekonomske politike. Da je zadat poslednji udarac neoliberalizmu i pečat stavljen na njegovu neefikasnost potvrđuje činjenica da mnogi svetski ekonomisti pristalice neoliberalne ekonomske politike, među njima čak i tvorac Washingtonskog konsenzusa John Wiliamson, otvoreno priznaju nedostatak neoliberalne ekonomske politike i neophodnost adekvatnog angažmana države kako bi se uspostavila i održala konjuktura tržišta.

$S$ druge strane, činjenica jeste ta da još uvek postoje ekonomisti radikalnih i tvrdih uverenja da je za nastalu globalnu ekonomsku krizu kriva državna intervencija. Međutim, takva njihova stajališta se zasnivaju samo na šturim i neadekvatnim dokazima. Međutim, ipak kada se realno sagledaju stvari postoje indicije da je država kriva ali u tom smislu što nije pravovremeno reagirala na sva ta dešavanja na svojim tržištima koja su prepuštena neoliberalnoj samoregulaciji odnosno laissez faireu.

\section{AZIJSKI TIGROVI}

Azijski tigrovi su epitet za privrede zemalja Tajvana, Južne Koreje, Singapura i Hong Konga kojeg su dobile zahvaljujući naglom privrednom razvoju u periodu od 60-tih do 90- tih godina XX veka. Postojanje Azijskih tigrova (Singapur, Hong Kong, Južna Koreja, Tajvan) i zemalja koje nastoje postati Azijski tigrovi (Malezija, Indonezija) dovelo je do enormnog rasta trgovinske razmene između SAD-a i Azijskih tigrova i rasta ulaganja SAD-a u Azijske tigrove. Važan faktor koji je uticao na visoku stopu privrednog rasta Azijskih tigrova jeste što su one napustile dotadašnju praksu oslobađanja od inostrane ovisnosti na način što bi se bazirale na svoje domaće i industrijske proizvode. Oni su ustvari se okrenuli izvozu tih svojih proizvoda u visoko razvijene zemlje. Još jedan bitan faktor koji je uticao na visoku stopu privrednog rasta jeste što su imali jeftinu radnu snagu. Naime, početkom 60- tih godina XX veka kada su Azijski tigrovi se svrastavali u nerazvijene zemlje oni su tada imali jeftinu radnu snagu. Tokom 60 -tih godina XX veka uz kvalitetne edukacije i obrazovanje oni su uspeli da dobiju kvalitetnu, produktivnu, a istovremeno jeftinu radnu snagu.

\footnotetext{
${ }^{49}$ M.Drašković, Globalna financijska kriza i neoliberalna dogma, Ekonomija/Economics 16-1, www.rifin.com, str.135.

${ }^{50}$ Ibidem, str. 135.
} 
Glavna obeležija koja su okarakterisala Azijske tigrove je visoka stopa štednje, razvijena ekonomija sa visokom stopom bruto-društvenog proizvoda po glavi stanovnika, zaštita domaćeg tržišta uvođenjem visokih tarifnih stopa, baziranje na izvoz domaće proizvodnje u visoko razvijene zemlje, stabilna stopa privrednog rasta $u$ dugugodišnjem vremenskom periodu koja se je kretala u dvocifrenim brojevima, i produktivna motivisana i jeftina radna snaga.

Azijski tigrovi će ostati upamćeni i po tzv. "Second Miracle on the Han River" što u prevodu znači "Drugo čudo na reci Han", kojim je okarakterisana Južna Koreja koja je u to vreme bila pod velikim uticajem krize, ali je uspela u periodu od tri godine da vrati sva dugovanja koja je imala prema MMF-u.

Što se tiče Tajvan u tom periodu on nije bio pod veiikim uticajem tadašnjih kriza i nalazio se je na 16-om mestu po brzini privrednog rasta. Prednosti koje je imao Hong Kong, a koje su znatno doprinele visokoj stopi privrednog rasta jeste njegova geografska pozicija na osnovu koje je imao status vodeće svetske luke i pre nego je postao britanska kolonija 1841.godine. Zajedničku prednost koju je delio i sa ostalim Azijskim tigrovima jesu ljudski resursi. Krajem XX veka Hong Kong je brojao nešto manje od 6 miliona stanovnika. Hong Kong čija ukupna vrednost uvoza i izvoza premašuje ukupan bruto društveni proizvod nalazi se na 11-tom mestu u svetu najvećih trgovinskih centara sveta. Kada govorimo o Singapuru i njegovoj ekonomiji može se reći da je intervencija države na tom tržištu minorna, odnosno da je tržište Singapura veoma liberalizovano sa najvećim bruto društvenim proizvodom po glavi stanovnika, te sa stabilnim cenama, i otvoreno poslovno okruženje. Kupovinu deficitarnih sirovina i prirodnih resursa Singapur ostvaruje pomoću prihoda nastalih izvozom proizvoda elektro industrije i hemijske industrije. Singapur kao i Hong Kong se može pohvaliti takođe sa svojim geografskim položajem koji mu omogućuje stratešku poziciju za luku. U periodu od 1960. pa sve do 1999. godine Singapur je ostvario stopu rasta proizvodnje u iznosu od $8 \%$, da bi 2000 . godine stopa rasta bila 9,9\%. Ekonomija Južne Koreje nalazi se na 4 mestu u Aziji, dok na svetskoj lestvici ona se nalazi na 13 mestu.

\section{ZAKLJUČAK}

Imajući u vidu sve veći stepen globalizacije svetskih tokova, kao dejstvo različitih faktora (nesavršenost tržišta, svetske ekonomske integracije i sl.) menja se i karakter poslovnih ciklusa. Vremenski period trajanja krize se sve više skraćuje, a posledice pada privredne aktivnosti su blaže. Otuda i činjenica da se za savremene poremećaje kapitalističke društvene reprodukcije upotrebljava naziv recesija51, koja se za razliku od krize javlja u kraćim vremenskim periodima, a praćena je stagfalcijom i slampflacijom, pošto je obeležava i rast inflacije. Ostale karakteristike recesije su iste kao u fazi krize, pa se za period kada počnu da opadaju investicije, raste nezaposlenost kaže da privreda ulazi u kontrakciju. Obrnuti proces se označava kao ekspanzija.

Poslovni ciklusi jesu sastavni deo makroekonomskog ambijenta od početka devetnaestog veka pa do danas. U cilju pronalaženja odgovora na aktuelne ekonomske probleme koji su pogađali, kako razvijene tako i manje razvijene ekonomije, razmatrani su različiti mehanizmi, u vidu raznovrsnih mera fiskalne i monetarne politike kako bi se ti problemi prevazišli. Tokovi razvija cikličnih fluktuacija određeni su kako specifičnostima svake nacionalne ekonomije, tako i sledom događaja u međunarodnom okruženju.

\section{LITERATURA}

1. M.Babić, Makroekonomija, Mate, Zagreb, 2007, str. 640.

2. Samjuelson P., Nordhaus V., Ekonomija, 18. izdanje, MATE Zagreb, 2009

3. M.Kesner-Škreb, Washingtonski koncenzus, Finansijska teroija i praksa, 28(2), 2004

4. Lj. Jurčić: Finansijska kriza i fiskalna politika, Ekonomski pregled 5-6, 2010,

5. Ž.S.Petrac,: Karakter tekuće finansijske krize SAD i moguće globalne posledice, Biblid br. 4, 2008,

6. S.Komazec, Ž.Ristić, Makroekonomija, Etno Stil, Beograd, 2009,

7. Lj. Jurčić: Finansijska kriza i fiskalna politika, Ekonomski pregled 5-6, 2010,

8. P. Berhnolz, Monetary regimes and inflation, Edward Elgar, 2003,

9. M.Friedman:The quantity theory of money: A restatement, citiran prema R.W. Clower: Monetary theory, Penguin, 1969

10.D.Ž.Marković, B.B.Ilić, S.Komazec, Ž.L.Ristić, D.D.Radovanović, Globalna ekonomija i geofinansije, Etno Stil, Beograd, 2011

11.J.Tobin, Keynesian models of recession and depression, American Economic Review, Papers and Procesings, 1975

${ }^{51}$ Bouls S., Edvards R., Razumijevanje kapitalizma, Školska knjiga, Zagreb, 1990, str. 269-270 


\section{ABSTRACT}

Economic trends indicate an imbalance and unevenness in the performance of the main economic process, ie the fact that capitalism is marked by boom and bust, recessions and expansions that are repeated. Beginning in 1825 and the first economic crisis, there are ups and downs in the performance of the world economy. In a highly developed market economy, a country may in a given period achieved economic expansion and prosperity, accompanied by the rapid growth of the gross domestic product, real-income, investment, employment. This trend is accompanied by certain measures of fiscal policy and meonetarne, whose errors in often require that the welfare states of Western Europe is entering into a crisis characterized by a rise in unemployment, the decline in gross domestic product, a drop in profits and others. The negative balance in most macroeconomic indicators after a period reaches the bottom, and then begins recovery of the economy, which may be shorter or longer time.

Key words: economic policy, the economic crisis, recession, neoliberalism. 